\title{
The Role of Tumor Suppressor Genes in Molecular and Biological Basis of Lung Cancer
}

\author{
Nikolaos Andreas Chrysanthakopoulos \\ Dental Surgeon (DDSc), Resident in Maxillofacial and Oral Surgery, 401 General Military Hospital of Athens, \\ Oncologist (MSc), Specialized in Clinical Oncology, Cytology, Histopathology, Dept. of Pathological \\ Anatomy, Medical School, University of Athens, Athens, Greece, PhD in Oncology (cand)
}

*Corresponding Author: Nikolaos Andreas Chrysanthakopoulos, Dental Surgeon (DDSc), Resident in Maxillofacial and Oral Surgery, 401 General Military Hospital of Athens, Oncologist (MSc), Specialized in Clinical Oncology, Cytology, Histopathology, Dept. of Pathological Anatomy, Medical School, University of Athens, Athens, Greece, PhD in Oncology (cand)

\begin{abstract}
Lung Cancer (LC) is the 5 th leading cause of cancer-related death in males and females worldwide and, it is also responsible for a high proportion of morbidity and mortality as the 5-year survival is extremely poor. LC is characterized by a large variety of genetic alterations and mutations that occur at high frequency. Improvements in molecular and biological basis of LC may lead to customized and personalized treatment based on targeting specific cellular signaling pathways and genes. Signaling pathways and genes that could be involved in LC treatmen include cellular signaling pathways which promote tumor's development, such as the Epidermal Growth Factor Receptor/Ras/ PhosphatidylInositol 3-Kinase (EGFR/Ras/PI3-K) pathway, pathways which inhibit tumor's development, such as the p53/Rb/P14ARF, STK11 pathway, apoptotic promoting pathways such as the Bcl-2/Bax/Fas/FasL pathway, immortalization genes which regulate senescencel immortalization and include regulator genes and pathways, such as the cell cycle $p R B / p 53$, cytoskeletal, interferon-related (IFN), insulin growth factor-related, MAP kinase and oxidative stress pathway, and, DNA repair defects and mutations. Epigenetic changes in LC also contribute strongly to cell transformation as they are able to modify the structure of chromatin and the specific gene expression and include DNA methylation, chromatin and histone modification, and micro-RNA, which are responsible for the silencing of tumor suppressor genes whereas enhancing oncogenes expression. The genetic and epigenetic pathways involved in lung tumorigenesis differ among LC histological types, and are tools for LC diagnosis, prognosis, clinical follow-up and targeted therapies. The current review, focuses on the presentation of molecular and biological events that are involved in LC development giving emphasis to tumor suppressor genes and signaling pathways that are implicated in LC development.
\end{abstract}

Keywords: Tumor Suppressor Genes, Signaling pathways, Mutations

\section{INTRODUCTION}

Lung cancer (LC) is the 2 nd most common cancer diagnosis by gender, behind prostate cancer for males and breast cancer for females [1]. The most common age of LC diagnosis is 70 years, whereas in most cases the prognosis is extremely poor as $17.4 \%$ of people in the United States that were diagnosed with LC survive five years after the diagnosis [2]. It is also responsible for a high rate of morbidity and mortality as advanced LC has extremely poor prognosis, with a 5-year survival of only 5\% [1].

LC pathogenesis has not been fully elucidated, whereas LC molecular and biological basis is complex and heterogeneous. LC development is a multistage process involving genetic alterations in DNA sequence, epigenetic modifications, activation of growth promoting pathways and inhibition of tumor suppressor pathways that result in DNA damage, contribute to cancer initiation, promotion and progression as regulate gene expression and cellular signaling pathways in the normal cells and transform normal lung epithelial cells into LC cells [3,4]. However, it remains unknown whether all lung epithelial cells or only a subset of those, such as lung epithelial stem cells or their immediate progenitors are susceptible to complete malignant transformation.

Moreover, whereas the tumor-initiating cells may have only a few mutations, as the tumor 
expands, cells may acquire additional mutations [5]. Previous researches have shown that those alterations usually occur early in malignant transformation $[6,7]$. Those alterations lead to LC development and exhibit the classical hallmarks of cancer, namely self sufficiency of growth signals, insensitivity to growthinhibitory/antigrowth signals, limitless replicative potential, evasion of programmed cell death/apoptosis, tissue invasion, sustained angiogenesis, and metastasis [8].

LC is divided into two main types based on histological, clinical, and neuroendocrine characterristics, non-small cell LC (NSCLC) and small cell LC (SCLC), their prevalence is $80 \%-85 \%$ and 15\%-20\%, respectively. Moreover, NSCLC is also divided into other histological subtypes, such as adenocarcinoma (LADC), squamous carcinoma (SCC), large-cell carcinoma (LCC), including large-cell neuroendocrine LC (LCNEC), bronchoalveolar LC, and mixed histological types, such as adenosquamous carcinoma (ASQC) [9].

The main histological types and subtypes of LC have also differences in molecular basis. In particular, those molecular differences between NSCLC and SCLC types and among NSCLC subtypes are associated with oncogenic mutations, increased protein expression, gene amplification, tumor suppressing alterations which include mutations, deletion and loss of heterozygocity $(\mathrm{LOH})$, loss of protein expression, tumor-acquired DNA methylation, chromosomal aberrations, and presence of telomerase activity. Various genes and cellular signaling pathways are responsible for the mentioned genetic alterations and are also implicated in cell functions such as growth, survival, differentiation, proliferation, programmed cell death, invasion, metastasis, etc., and include oncogenes (ONG) and tumor suppressor genes (TSG), such as BRAF, KRAS, MET, PIK3CA, EGFR, ErbB2/HER 2-neu, MDM2, MYC, PDGFRA, Bcl-2, CCND1, p53, Rb, PTEN, LKB1, CDKN2A (p16/p14ARF), FHIT, CAV1, APC, TUSC2, CDH 1, CDH 13, DAPK1, GSTP1, MGMT, RAR $\beta$, RASSF1A, SEMA3B,TIMP3, EML4-ALK fusion, etc. [9].

In LC as in other malignancies, oncogenesis is associated with growth promoting proteins activation such as, KRAS, EGFR, BRAF, MEK1, HER2, MET, ALK as well as inactivation of TSGs, such as P53, PTEN, LKB1 [3]. Activation of growth promoting oncogenes can occur by gene amplification or other genetic alterations including point mutations and structural rearrangements leading to uncontrolled signaling through oncogenic pathways [10].

A better understanding of molecular alterations and the multiple biochemical pathways involved in the molecular pathogenesis of LC at multiple levels, genetic, epigenetic, protein expression and their functional significance, are crucial to the development of treatment strategies that can target molecular aberrations and their downstream activated pathways [9], and could be contribute to LC diagnosis, treatment and prognosis. Moreover, cell survival depends on continued activation of the aberrant signaling [10] making them ideal candidates for targeted treatments. Identifying the genes and pathways involved, determining how they relate to the biological behavior of LC, and their utility as diagnostic and therapeutic targets are important basic and translational research issues. Consequently, current information on the crucial molecular stages in LC pathogenesis regarding the role of TSGs and their involvement in preneoplasia, primary cancer, and metastatic disease is the aim of the current review.

\section{TUMOR SUPPRESSOR GENES}

It is known that TSGs negatively regulate cell growth .Their function is crucial for carcinogenesis and requires inactivation of both gene alleles, according to Knudson's two hit hypothesis. Mutation, epigenetic silencing or other aberrations, are responsible for the inactivation of the individual gene in one allele. The 2 nd allele in some cases is targeted by deletion (homozygous deletions), methylation with consequent loss of expression, or mutation [11]. The final result is that the 2 nd allele is inactivated due to $\mathrm{LOH}$, leading to loss of a chromosome region by deletion, nonreciprocal translocation or mitotic recombination. The most frequently inactivated TSGs in LC cases are TP53, retinoblastoma1(RB1), PTEN, RASSF1A, CDKN2A, Serinethreonine Kinase 11 (STK11/LKB1), and FHIT [9,12], and chromosomal regions that exhibit allelic loss in LC cases involve TSGs such as TP53 (17p13), PTEN (10q22), p16 (9p21), and RB1 (13q12) [12].(Fig. 1)

\subsection{Pten Tumor Suppressor Gene}

PTEN (phosphatase and tensin homolog) is a TSG which is mutated in many hereditary and sporadic human cancers, is located on 10q23 chromosome, encodes a protein that acts as a 
dual lipidand protein phosphatase, and inhibits the PI3K/AKT/mTOR signaling pathway by the dephosphorylation of the PI- $(3,4,5)$ triphosphate. PTEN inactivation causes unlimited activation of AKT/protein kinase B which is independent of ligand binding [13].PTEN mutations have been identified in $5 \%$ of NSCLC cases [14]despite the fact that in NSCLC type has found reduced protein expression in about $75 \%$. Those mutations are more frequent in SCC (10.2\%) than LADC cases $(1.7 \%)$ and are also associated with a smoking history [15].The Nuclear Factor-kappa B (NF-kB) activates the transcription of Snail, which is a PTEN transcription suppressor, therefore PTEN is negatively regulated by NFkappa B [16]. It has been demonstrated that NFkappa $\mathrm{B}$ activation was necessary and sufficient for inhibition of PTEN expression in a subset of human LC cells [17].

\section{FHIT TuMOR SUPPRESSOR GENE}

The fragile histidine triad (FHIT) gene, a candidate TSG, was recently identified on chromosome 3p14.2. FHIT gene encompasses the common fragile site FRA3B on chromosome 3 , where carcinogen-induced damage can lead to translocations and aberrant transcripts of it [18].FHIT function has been investigated in several tumors by the upregulation of inducing cell cyclearrest, cell proliferation inhibition, and apoptosis by increasing its sensitivity to DNA damagingagents [19,20].

FHIT gene is inactivated by $\mathrm{LOH}$ and methylation in cancer cells, whereas the occurrence of mutations is very rare [21]. FHIT promoter hypermethylation that leads to FHIT inactivation and FHIT protein expression lack, has been identified to play a crucial role in lung alveolar differentiation, regulation and epithelial tumorigenesis [22-24]. FHIT gene is inactivated in $50 \%$ to $70 \%$ of all LC cases [25].

Abnormal FHIT transcripts, including exons deletions, insertions between exons, and insertions that replace exons, have been identified in a high proportion of LC cases. Reduction or complete loss of FHIT expression have been found in about 30\%-70\% of NSCLC cases and in about $20 \%$ of bronchial biopsies from chronic smokers without evidence of LC, finding that supports the theory that FHIT gene is a molecular target of tobacco smoke carcinogens [26]. In a study by Fong et al. primary LCs, tumor cell lines, and preneoplastic bronchial lesions were examined for molecular genetic abnormalities in FHIT gene, which links the FRA3B fragile site on 3p14.2region, and the outcomes showed that $3 \mathrm{p} 14.2$ allele loss was existed in $100 \%$ of SCLC and $88 \%$ of NSCLC cell lines and $45 \%$ of primary NSCLC cases and rare in LADC cases, with manybreak-points. Those findings suggest the involvement of several distinct regions in the FRA3Bsite. Homozygous deletions within the FHIT/FRA3B region were found in $4.4 \%$ of thoraciccancer cell lines [27].

\section{ApC Tumor SuPPRESSOR GENE}

Adenomatous polyposis coli (APC) is a protein that is encoded by the APC gene, a TSG andconstitutes a negative regulator that controls beta-catenin concentrations as acts as an antagonistof the Wnt signaling pathway. It also interacts with E-cadherin, which is implicated in cell adhesion, cell migration, transcriptional activation, and apoptosis [28].APC gene mutations may result in colorectal cancer [29], as cause familial adenomatous polyposis (FAP), finding that suggests its role as a potential predictor for cancer initiation or development.

It has been found that APC gene promoter methylation, inhibits its expression, and is mediated by changes of chromatin modulation and aberrant binding of CCAAT-box binding transcription factors [30]. Previous studies have shown that APC promoter hypermethylation in NSCLC cases has been reported as an effective biomarker for diagnosis [31, 32], as in general, the link between APC hypermethylation with cancers has been extensively assessed [33]. However, the results ofthose studies are controversial because of differences in epidemiological parameters examined and analyzed, detection methods, etc. $\mathrm{LOH}$ on chromosome 5q, the APC locus, is a frequent finding in LC cases, however previous studies have recorded no APC mutations. In a study by Ohgaki et al. [34], 114 human LC specimens were investigated for alterations in the mutation cluster region of the APC gene and revealed APC mutations in $5 \%$ of SCC cases, findings that suggest that APC mutations are infrequent, but may be involved in the pathogenesis of a small subset of LC cases.

\section{STK11 (LKb1) TUMOR SUPPRESSOR GENE}

Serine/threonine kinase 11 (STK11or LKB1) gene encodes a serine/threonine kinase, is locatedon $19 \mathrm{p} 13$ chromosome, and functions as a TSG [35]. It acts as a mTOR inhibitor through mTOR path way inhibition via adenosine monophosphate-activated protein kinase (AMPK) [36] and regulates differentiation, 
metabolism, cell polarity, motility and metastasis [35], whereas is alsoimplicated in cell cycle regulation, and chromatin remodeling [36, 37]. mTOR signaling path way components deregulation, except for KRAS mutations, has been identified in $30 \%$ of LADC cases [38].STK11 gene inactivating mutations are responsible for Peutz-Jeghers syndrome [39], however somatic inactivation caused by point mutation and deletion on 19p13 are presented in $30 \%$ of LC cases, and constitutes the 3 rd most commonly mutated gene in LADC, caused by various somaticmutations or deletions that produce abnormal proteins, after p53 and RAS [38, 40-42]. STK11gene inactivating mutations are often associated with KRAS activation and can lead to cell growth promotion [42], are more common in poorly differentiated LADC cases, whereas are rarein SCLC cases [40, 42, 43]. Moreover, STK11 gene inactivation is more frequent in LADC compared to SCC cases [40, 41]. An association has been recorded between STK11 gene mutations and smoking in males [41, 42, 44], and an association with KRAS mutations has also been found $[41,42]$.

\section{TUSC2 TUMOR SUPPRESSOR GENE}

Tumor suppressor candidate 2 gene (TUSC2), also known as FUS1, is considered as a candidate TSG. TUSC2 functions are still remain unclear. Previous researches showed that TUSC2 induces G1 cell cycle arrest and apoptosis [45, 46], regulates calcium signaling [47], modulates tyrosinekinases [48], and affects gene expression [49].It is located on chromosome 3p21.3 which is homozygously deleted in lung and breast cancers.TUSC2 is considered as a TSG in LC cases as its mRNA expression loss has been recorded in $80 \%$ of the tumors, because of $3 \mathrm{p} 21.3$ deletion [50]. It has also recorded that $3 \mathrm{p} 21.3$ deletion was very rare in LC cases (1.1\% TCGA), except for malignant mesothelioma (36\%) [49], where asno evidence of methylation was identified in the TUSC2 gene promoter region in LC cases [46].TUSC2 promoter region was partially methylated in oral tumors but unmethylated in normalmucosa [51]. TUSC2 somatic mutations have not been observed in any cancer specimens according to TCGA, although infrequent mutations have been identified in LC cell lines [46].

\section{CDH1 Tumor SuPPRESSOR GeNE}

CDH1/E-cadherin is a cell-cell adhesion transmembrane glycoprotein, and is encoded by theCDH1 gene which is located on 16q22.1 region [52]. CDH1 is a TSG and plays a critical role in maintaining cell adhesion and adherent junctions in normal tissues. Its expression is frequently absent in several epithelial tumors, and loss of normal intercellular junctions can promote cancerinvasion and metastasis, whereas it is also associated with several types of cancers $[53,54] . \mathrm{CDH} 1 \quad$ loss promotes $\beta$-catenin translocation into the nucleus, and regulates transcription of various targeted proteins [55]. It is also implicated in epithelial-mesenchymal transition (EMT) which is the crucial early step for cancer metastasis [56]. Therefore, CDH1 low expression levelis associated with tumor invasiveness, metastasis, and poor prognosis. It has also found that decreased expression of $\mathrm{CDH} 1$ is responsible for the malignant phenotype of NSCLC [57], andCDH1 promoter methylation is associated with LC cases [58].Ybox binding protein-1 (YBX1) is over-expressed in various tumors including LC cases and serves as a novel marker of LC progression [59]. In a study by Stella et al. [60] was found thatdownregulated $\mathrm{CDH} 1$ strengthens EGFR transcription in a phospho-YBX1 dependent way and contributes to cell proliferation and metastasis in NSCLC cells. YBX1 plays a critical role in EGFR up-regulation, which consequently promotes cell proliferation and invasion ability in NSCLC cells. However, the mechanism that loss of CDH1 promotes NSCLC metastasis needs further investigation. Moreover, Xianfang et al. found down-regulation of $\mathrm{CDH} 1$ upregulated EGFR transcription levels in NSCLC cells [61].

\section{CDH 13 TumOR SuPPRESSOR GENE}

Cadherin 13, constitutes a member of the cadherin family, is coded by the CDH13 gene, which islocated on chromosome 16q24.2 [62]. Cadherin proteins are implicated in the formation of intercellular junctions, such as $\mathrm{N}$ and E-cadherin. In many epithelial cancers has been identified lossof cadherin expression and may play a critical role in malignant cell invasion and metastasis[63].Recent researches have shown that $\mathrm{CDH} 13$ functions as an antioncogene in lung [64], breastcancer [65] and in other organs, whereas downregulation of its expression could promote cancer progression. Toyooka et al. [66] were observed that CDH 13 expression is reduced in LC cases, and that its down regulation could be attributed to hypermethylation in the $\mathrm{CDH} 13$ promoter. In another study was found that single nucleotide polymorphisms (SNPs) in CDH13 gene could affect themethylation of $\mathrm{CpG}$ islands in $\mathrm{CDH} 13$ 
gene [67]. Several studies have reported that SNPs inCDH13 gene were associated with cancer, such as colorectal and LC [62-64,6669]. However, few studies have investigated the association between SNPs in CDH13 gene and NSCLC cases [70].

\section{RASSF1A TUMOR SUPPRESSOR GENE}

The RASSF1A gene constitutes a TSG which is located on chromosome 3p21, it acts at the pointof G1/S phase cell cycle progression, inhibits the accumulation of Cyclin D1, and thus induce cell cycle arrest [71]. 3p21 location is epigenetically inactivated at high frequency in NSCLC cases. RASSF1A binds to the Ras-GTP binding protein Nore1, as a Rasoncoprotein negative effector [72]. In LC cells RASSF1A promoter is hyper methylated and the exogenous expression ofRASSF1A expresses tumorigenesis in nude mice [73]. Moreover, it has been identified that theRASSF1A gene is frequently inactivated in primary LC cases by the de novo methylation of $\mathrm{CpG}$ islands in the promoter location [74].

\section{Sema Family as Tumor Suppressor GENES}

The semaphorin/collapsing family of molecules are implicated in neuronal development and has been shown that act as TSGs by inducing apoptosis. SEMA3 proteins are also involved invarious functions such as immune formation [75], organogenesis [76], neuronal apoptosis [77], and drug resistance [78]. Semaphorin3B (SEMA3B) is located on 3p21.3 chromosome, a location that is associated with increased allele loss and/ or promoter methylation in the early pathogenesis of lung and breast cancer [78, 79], belongs to the class 3 semaphorins and constitutes a secreted protein [80].

SEMA3B gene encodes a protein with tumor suppressor activity for LC [81]. Previous studies showed that treatment by using exogenously SEMA3B or import of a plasmid encoding SEMA3B in H1299 NSCLC cells reinducted apoptosis and a significant reduction in colony formation[78,81], whereas tumor-acquired SEMA3B missense mutations do not show such functions. In another study was found that SEMA3B expression in a p53-negative glioblastoma cell line was increased after p53 reexpression, finding that suggest SEMA3B function as a mediator of p53tumor-suppressor activity. However, because H1299 cells are p53 null, SEMA3B can induce tumor suppression even in the absence of p53 [82].

\section{CAv1 As A TumOr SuPPRESSOR GENE}

Caveolin-1 (Cav-1), a major structural protein of caveolae, that are plasma membrane invaginations

are implicated in cellular processes, such as lipid transport, cell adhesion, molecule transport, signal transduction, and tumor progression [83]. Recent researches suggests that Cav-1 has a positive regulatory effect on tumor growth and plays a central role in tumor invasion and metastasis, despite the fact that seems to function as a tumor suppressor protein at early stages of cancer progression [84,85]. Cav-1 regulates the activity of several pathways, including EGFR, Src family kinases, G-proteins, $\mathrm{H}$-Ras, protein kinase $\mathrm{C}$, endothelial nitric oxide synthase, andintegrins, which are potentially implicated in the development of cancer, by forming signaling complexes [83]. Therefore, Cav-1 could be a key molecule for growthrelated signaling and cancer development.

It has been suggested that Cav-1 gene acts as both a TSG and an ONG. Its expression is down-regulated in lung, colon and other cancers, whereas cell oncogenic transformation has been associated with reduction of its expression, and antisense-mediated downregulation of its expression could lead to oncogenic transformation in NIH 3T3 cells [8688]. On the contrary, other reports have shown that Cav-1 expression was found to be upregulated in several cancers such as esophagus and LC [89, 90]. Moreover, Cav-1 exogenous expression in malignancy transformed cells and cancer cell lines inhibited cell growth and tumorigenesis, observation that indicates its roleas a TSG [91, 92].

\section{Mgmt Tumor Suppressor Gene}

O-6-methylguanine-DNA methyltransferase (MGMT), is a specific DNA damage reversal repairprotein, which protects tissues against the carcinogenic and toxic effects of methylating andchloro-ethylating agents by removing adducts from $\mathrm{O} 6$ position of guanine and prevents mis-match and errors during DNA replication and transcription [93].MGMT has been reported as a TSG in colorectal cancer [94], whereas its epigenetic silencing caused by its promoter methylation at specific $\mathrm{CpG}$ islands can lead to loss of its activity in several cancers, including LC $[95,96]$. The methylation status of the MGMT promoter has been observed in some cancers, such as NSCLC [97], glioblastoma 
[98], breast cancer [99], and others. In NSCLC cases has been identified a varying level of MGMT promoter methylation frequency[74,100], observation that could be attributed to various nature of the clinical samples, that were analyzed. Previous metaanalysis studies have shown that MGMT methylation is associated with NSCLC incidence [101-103], but those studies were based on a small amount of various samples and therefore could lead to unreliable outcomes, as they recorded quite different ratesof MGMT hyper-methylation from different samples, whereas only the samples from tumortissue showed higher methylation compared to control group $[101,102]$. Moreover, those studies have also not completely investigated the association between MGMT methylation and clinical characteristics of NSCLC, but only analyzed the risk between MGMT methylation and NSCLC[101-103].

\section{TP53 TumOR SUPPRESSOR GENE}

TP53 gene is located on chromosome $17 \mathrm{p} 13$, encodes a nuclear phosphoprotein of $53 \mathrm{kDa}$ that identifies and binds to regions of damaged DNA [104] and acts as a transcription factor controlling the expression of a large number of different genes. It is induced in case of DNA damage orcarcinogenic or oxidative stress and leads to cell cycle arrest by inducing expression of Cyclin Dependent Kinase (CDK) inhibitors which regulate cell cycle checkpoint signals, causing the cell to undergo G1 arrest and allowing DNA repair or programmed cell death/apoptosis. As atranscription factor has downstream target genes involving cell cycle arrests G1 and G2, DNA repair or apoptosis, and upstream regulatory genes, including p14ARF and MDM2. MDM2and p14ARF are implicated in cases of abnormal functions of $\mathrm{p} 53$ protein. p14ARF is a crucial TSG, is encoded in the 9p21 locus of p16INK4 from an alternative exon $1 \beta$, responding to both oncogenic stimuli (Ras, MYC, E2F1) and DNA damage and its activation induces $\mathrm{G} 1$ arrest andapoptosis, either dependently or independently of p53 protein $[105,106]$.TP53 TSG is the most frequently mutated gene in LC cases [107], whereas p14ARF protein expression loss, due to yet unknown mechanisms, occurs frequently in SCLC, LCNEC and in some LADC cases [108]. MDM2 amplification is rare, almost $6 \%$ of NSCLC cases, although over expression at the level of mRNA and protein is frequent, occurring in $30 \%$ of both SCLC and NSCLC cases [105].

TP53 gene's inactivation is one of the most significant genetic abnormalities in LC cases with hemizygous deletion of $17 \mathrm{p} 13$, containing the locus of TP53, occurring in $90 \%$ of SCLC case sand about $65 \%$ of NSCLC cases [109]. Inactivating mutations of the TP53 gene which most of them are missense mutations within the DNA-binding domain, have been identified in $80-100 \%$ of SCLC cases, in $90 \%$ of LCNEC cases and in $50 \%$ of NSCLC, of which gain-offunction mutations prevent the p53 protein binding to MDM2 and subsequent p53 ubiquitin-dependentproteolysis [110-112]. Moreover, in a meta-analysis by Tammemagi et al. [113] in over 4,000NSCLC cases were recorded alterations by mutation or protein accumulation in only $46.8 \%$ ofthose cases, more commonly in SCLC than LADC cases and were associated with higher tumorgrade, stage and male gender. In a comprehensive genomic analysis according to The Cancer Genome Atlas (TCGA) project [114] mutations of TP53 gene were recorded in at least $81 \%$ of SCLC cases. In another research was recorded TP53 gene mutations in 85 of 188 LADC cases(45\%) [38]. TP53 gene mutations in NSCLC cases, are associated with a positive history of smoking or exposure to env cironmental tobacco smoke $[115,116]$. The range of mutations of different types of TP53 gene mutations is different between smokers and non-smokers and it has been observed that smoking-related cancers show a significantly higher frequency of GC to TA transversions at $\mathrm{CpG}$ islands compared to $\mathrm{G}$ to $\mathrm{C}$ transversions, which were induced by PAHs intobacco smoke, and $\mathrm{G}$ to A transitions at $\mathrm{CpG}$ dinucleotides more commonly found in neversmokers [116,117]. On the contrary, GC to $\mathrm{TA}(\mathrm{G}-\mathrm{A})$ transition at non-CpG islands were associated with LC in never-smokers $[111,112] . T P 53$ gene alterations and stabilization by mutation are frequent in proximal pre-invasive lesions of squamous dysplasia type and carcinoma in situ $[111,112]$. In a meta-analysis of 74 studies was recorded that aberrant TP53 gene detected by protein expression or mutational analysis was anadverse prognostic factor in NSCLC cases [118]. Some point mutations in TP53 gene accord again-offunction phenotype leading to increased aggressiveness of LC [119]. TP53 gene mutations can occur in association with KRAS and EGFR mutations [115], whereas genetic alterations of TP53 gene have also been 
associated with treatment resistance [104].Ataxia telangiectasia mutated (ATM) gene is another gene upstream of the p53/p14ARF pathway, and mediates the response to DNA damage. It is known to be mutant in ataxia telangiectasia disease, characterized by a lack of DNA repair, but is not known as a mutant in $\mathrm{LC}$ cases. Arecent DNA sequencing of 623 genes in 188 LADC cases showed ATM to be mutant in $14(7.4 \%)$, thus contributing the strong targeting of p53 pathway functions in LC cases [38].The downstream p53 pathway includes target genes of TP53 transcription, which play key rolesin the mitochondrial apoptotic pathway, as well as in the death receptor pathway Bcl-2 as antiapoptotic and Bax as pro-apoptotic, are up and down regulated by $\mathrm{p} 53$, respectively, Fas and the tumor necrosis factor receptor (TNFR)like apoptosis inducing ligand (TRAIL) receptor DR5(TRAIL-death receptor 5) belong to the TNFR family. Those four factors are strongly deregulated in LC cases, which results in strong resistance to both mitochondrial and death receptor-induced apoptosis [120].

\section{RAR AS TUMOR SUPPRESSOR GENES}

The retinoic acid receptor (RAR) is a type of nuclear receptor, act as a transcription factor [121] and is activated by both all-trans retinoic acid and 9-cis retinoic acid [122]. Two families of retinoic receptors have been identified, RARs and RXRs with three subtypes for each $(\alpha, \beta$, $\gamma$ )and several isoforms arising from promoter usage and alternate splicing and are encoded by the RARA, RARB, RARG genes, respectively. Moreover, RAR genes expression is under epigenetic regulation by promoter methylation $[122,123]$. The effects of retinoids are mainly mediated by the nuclear retinoid receptors, which are members of the steroid and thyroid hormone receptor super family [124]. The biological functions of the multiple isoforms of RARs are still remain unclear, however, those isoforms could explain the implication of RARs in various biological effects. It has been shown that the absence of two isoforms for $\operatorname{RAR} \alpha(\alpha 1$ and $\alpha 2)$ and for $\operatorname{RAR} \gamma(\gamma 1$ and $\gamma 2)$, and four isoforms for $\operatorname{RAR} \beta(\beta 1-\beta 4)$ and $\operatorname{RAR} \beta 1$ [125], could be responsible for retinoid resistance in lung carcinogenesis [126].

RAR $\beta 2$ isoform is located on $3 p 24$ region and its expression was reduced or even suppressed in LC cell lines, suggesting that its reexpression could suppress LC progression [127]. Loss or reduced RAR $\beta 2$ expression has been identified in a high frequency in heavy smokers in
NSCLCs and bronchial biopsy specimens $[128,129]$, and in other solid tumors [130,131].In a previous study was observed that RARs and RXRs were expressed in $89 \%$ of controlnormal bronchial tissue specimens in healthy individuals and that in distant normal bronchusspecimens in NSCLC patients $\mathrm{RAR} \alpha$, RXR $\alpha$ and $\gamma$ were expressed in more than 95\% of the tumor-free specimens. However, RAR $\beta$, RAR $\gamma$ and RXR $\beta$ expression was reduced, and was observed in $76 \%$ of NSCLC specimens [128], finding that was in line with another research in which was recorded reduced or absent RAR $\beta$ protein expression in 50\% of resected NSCLCsspecimens [132]. In the mentioned studies was found normal or elevated RAR $\alpha$ and RXR $\alpha$ expression in NSCLC specimens, whereas $\mathrm{LOH}$ at the region $3 \mathrm{p} 24$, in which is located RAR $\beta$ genewas identified in a high frequency, and was also found in nonneoplastic lesions, suggesting that modified retinoid receptor expression may be involved in lung carcinogenesis.

The abnormal methylation of the genes promoter regions consists a mechanism of gene silencingin cancer [133]. As it has been mentioned RAR genes expression is under epigenetic regulation by promoter methylation $[122,123]$. RAR $\beta$ gene hypermethylation frequently leads to loss of RAR $\beta$ expression which has been recorded in $43 \%$ of primary resected NSCLC samples [134]. It is also implicated in the pathogenesis of SCLC, whereas it was found that LC cell lines treatment with the demethylation agent 5-aza2\&39;-deoxycytidine (5-AZA-CdR) could restore RAR $\beta$ expression. RAR $\beta$ gene's mRNA expression loss has been detected in many LC cell lines, observation that indicates its role as a TSG [135].

\section{CDKn2A Tumor SupPressor Gene}

CDKN2A, also known as CDK inhibitor 2A, is a gene which in humans is located on chromosome $9 \mathrm{p} 21.3$. The gene codes for two proteins, including the INK4 family member p16 (or p16INK4a) and p14 ARF. Both act as TSGs by regulating the cell cycle. p16 inhibits CDK4 and -6and activates the RB family of proteins, which prevent the transition from G1 cell cycle phase toS-phase. p14ARF activates and interacts with the TP53 TSG [136].Somatic mutations of CDKN2A are common in the majority of human cancers, and it has been assessed that CDKN2A gene is the 2 nd most 
commonly inactivated gene in cancer after TP 53.It has been shown that in LADC cases often exist genetic mutations in CDKN2A gene which leads to inactivation of p16 and is one of the most common genetic alterations in many forms of cancer including LADC [137-139].

Both alleles must be inactivated before its function is eliminated. In its inactivation are implicated mechanisms such as homozygous deletion (HD), hypermethylation in the promoter $\mathrm{CpG}$ island (methylation), and point mutation. p16 is frequently inactivated by HD or promoter hypermethylation, and rarely by point mutation in primary NSCLC cases $[137,140]$. It has also been observed that the frequency of p16 methylation is significantly higher in LADC with KRA Smutation, however, the associations between p16 inactivation mechanisms and other common genetic mutations in LADC such as EGFR and STK11 remain controversial or have never been investigated [141]. Associations between smoking and p16 methylation and between p16 HD and never smokers have been recorded in some researches, however those findings are thought to be inconsistent [137,140142].

\section{RB TUMOR SUPPRESSOR GENE}

Retinoblastoma (RB) was the first TSG which discovered based on an association with a rare childhood tumor, retinoblastoma [143]. The Knudson hypothesis of a 2 nd hit in retinal cells of children with germline mutation led to the understanding the role of TSGs in cancer development [11]. A rate of $40 \%$ of retinoblastomas are hereditary and individuals with hereditary retinoblastoma are at high risk for malignancies such as breast cancer, melanoma, LC, osteosarcoma, bladder cancer and other epithelial cancers [144,145]. Somatic alterations in RB1 gene arecommon in various malignancies including LC, bladder, prostate, and breast cancer. RB1gene islocated on chromosome 13q14.1-q14.2.region, encodes the retinoblastoma pocket protein (RB)and is a downstream effector of p53-mediated G1 arrest through activation of the CDK inhibitorp21. CDK inhibitors, such as p16INK4A, p15INK4B, maintain $\mathrm{RB}$ in the unphosphorylated, active form. RB protein is implicated in the cell cycle regulation by binding to the unphosphorylated form of E2F transcription factors and suppresses their activity. After mitogenic stimulation,the CDKs, such as CDK4,CDK-6, Cyclin D and CDK2cyclin $\mathrm{E}$ phosphorylate $\mathrm{RB}$, which leadsto release of the binding to E2F factors and progression through the cell cycle, and finally leads to G1-S transition [146]. RB, in addition to regulation of cell proliferation has also a crucialrole in the regulation of EMT [147,148] and a possible role in immune response [149]. The absence of RB protein, is the most frequent mechanism of escape from G1 check-point in SCLC cases, whereas the RB hyperphosphorylation in NSCLC cases which is a common event, disarranges the G1 checkpoint control. Loss of RB protein occurs in more than $70 \%$ of highgrade LCNEC, in more than $90 \%$ of SCLC tumors, and in only 10-15\% of NSCLC cases [150].

A wide analysis of DNA sequences in LADC also identified RB1 mutation in some cases [38]pointing to the persistent negative selection for RB functions in LC cases (loss, phosphorylationand mutation) in addition to $\mathrm{LOH}$ at $13 \mathrm{q} 14$ (allelic loss) which is common in NSCLC cases [151,152]. Inactivation of RB functions by phosphorylation is mainly caused by the loss of p16INK4A expression and/or over expression of Cyclin D1 and Cyclin E, has been detected in NSCLC cases [120].CDK4 is rarely over expressed but is amplified in a small subset of NSCLC cases. On the contrary, Cyclin D1 over expression and p16INK4A loss have been observed in $40-50 \%$ of NSCLC cases [153], whereas previous studies showed that overexpression of Cyclin D1 gene (CCD1) was observed in $35-50 \%$ of NSCLC cases and both CCD1 over expression and p16INK4A loss were early phenomena, and were present as soon as pre-invasive lesion appeared, with an increasing squamous dysplasia grade level $[112,154]$. Cyclin D1 is rarely amplified in LC, however, asmall percentage of amplification of CCD1 was recently identified in a wide genomic characterisation of the LADC. Moreover, Cyclin D1 (CCND1) and Cyclin E (CCNE2) genes were foundamong the top focal regions of amplification in LADC cases [151].Loss of p16INK4A expression is attributed to its methylation in $40 \%$, its homozygous deletion in $30 \%$ and its mutation in $10 \%$ in cases of expression losses [153]. Allelic loss in 9p21 region (p16INK4A loss of allele $\mathrm{LOH}$ ) which contains the protein-coding genes CDKN2A and CDKN2Bis a frequent genetic aberration and 
leads to the p16 functions attenuation in addition to methylation [151].

A reverse relationship between Cyclin D1 over expression and RB loss shows that Cyclin D1 andp16INK4 are the only factors of RB phosphorylation that are not implicated in cases of RB lost, situation that is obvious in SCLC cases, in which RB is mostly lost, but Cyclin D1 or p16INK4alterations are rare. In contrast to previous observation, Cyclin E may be over expressed in $30 \%$ of SCC cases, in the absence of $\mathrm{RB}$, because of the Cyclin $\mathrm{E}$ response to DNA damage and genetic instability. Cyclin E over expression is an early event in LC bronchial preneoplasia [112].

\section{DAPK TUMOR SUPPRESSOR GENE}

Death-associated protein kinase (DAPK) is a pro-apoptotic $\mathrm{Ca} 2+$ calmodulin-regulated serine/threonine kinase which is implicated in various cellular functions, promotes either apoptosis initiated by interferon (IFN)- $\gamma$, or autophagic cell death in response to various stimuli, including ONGs, transforming growth factor- $\beta$ (TGF $\beta$ ), activation of Fas/CD95 receptors detachment from extracellular matrix, and tumor necrosis factor- $\alpha(\mathrm{TNF} \alpha)[155,156]$.

DAPK-1 is a tumor suppressor protein and shows metastatic inhibition properties, whereas hypermethylation DAPK gene promoter has been identified in some types of cancers, leadingto its functional loss rather than mutation $[157,158]$. DAPK dysfunction may be more crucial for the tumorigenesis of LC because of the high frequency of DAP-kinase promoter methylation onaverage in $40.5 \%$ of LC cases [159-163]. Less frequently, DAPK expression loss can be attributed to homozygous deletion DAP kinase CpG island [164].

\section{GSTP1 ENZYMES AS TUMOR SUPPRESSORS}

Human genes polymorphism that encodes enzymes which are implicated in metabolic activation and detoxification of lung carcinogens such as PAHs and aromatic amines has been revealed. Genetic differences among individual differences in their ability to activate and deactivate/detoxify these lung carcinogens are expected to affect the risk of LC developing [165].Glutathione S-transferases (GSTs) are phase II transformation enzymes implicated in the detoxification of dangerous agents [166]. GST gene family encodes genes that are critical for detoxication and toxification mechanisms, as the main role of GSTs is to detoxify dangerous agentsby catalyzing the nucleophilic attack by glutathione synthetase on electrophilic carbon, sulfur, ornitrogen atoms and transforms to non polar compounds, preventing their interaction with crucialcellular proteins, nucleic acids, and other cellular components [167]. A review by Altinisik et al., which examined the role of GST genetic polymorphisms to LC in different populations and based on previous reports led to contradictory results [168]. Several classes of GST, including Alpha, Mu, P1, and Theta, were previously found in human tissues. GSTP1 is the most predominant GSTs in lung tissue also considered to be most important in determining risk for LC development [169]. GSTP1 gene is located on chromosome 11q13, four GSTP1 alleles have been recognized, GSTP1A-D, encodes a phase II metabolic enzyme that detoxifies reactive electrophilicintermediates, plays a crucial role in protecting cells from carcinogenic and cytotoxic agents andis expressed in normal tissues at variable levels in different cell types. Altered GSTP1 expression and activity have been identified in many tumors and could be mainly attributed to GSTP1 DNA hypermethylation of $\mathrm{CpG}$ island in the promoter-5\&39; [170].SNPs in GSTP1 have been identified frequently and concern rs 1695 and rs1138272 [171,172].GSTP1 has the highest specific activity regarding the active benzo (a) pyrenediol epoxide, whichis a cigarette metabolite, is almost exclusively active to the positive-enantiomer of anti-benzopyrenediol epoxide, which is considered to be the final mutagenic form of benzo (a) pyrene[173], whereas its accumulation is associated with LC development [174].

During cancer development, GSTP1 does not seem to act either as an ONG or as a TSG, since induced GSTP1 expression in cancer cell lines failed to suppress cell development. Instead, GSTP1 was proposed to act as a \&quot; caretaker \& quot; gene. In cases of GSTP1 inactivation, cells appear tobecome more unprotected to somatic alterations upon chronic exposure to genome-damaging stresses as oxidants and electrophiles that are contributed by environment and lifestyle [175]. 
The Role of Tumor Suppressor Genes in Molecular and Biological Basis of Lung Cancer

\begin{tabular}{|c|c|c|c|}
\hline \multirow[b]{2}{*}{ GENES } & \multirow[b]{2}{*}{ SCLS } & \multicolumn{2}{|c|}{ NON SMALL CELL LUNG CANCER (NSCLC) } \\
\hline & & LADC & SQCLC \\
\hline \multicolumn{4}{|l|}{ TSGs ALTERATIONS } \\
\hline \multicolumn{4}{|l|}{ MUTATIONS } \\
\hline PTEN & $15-20 \%$ & 二 & 一 \\
\hline $\mathbf{R b}$ & $80-100 \%$ & - & - \\
\hline p53 & $75-90 \%$ & $50-70 \%$ & $60-70 \%$ \\
\hline LKB1 (STK11) & RARE & $30-60 \%$ & $5-30 \%$ \\
\hline CDKN2A (P16) & $<1 \%$ & - & - \\
\hline \multicolumn{4}{|c|}{ PROTEIN EXPRESSION LOSS } \\
\hline PTEN & - & $77 \%$ & $70 \%$ \\
\hline FHIT & $80-95 \%$ & - & - \\
\hline CAV-1 & $95 \%$ & - & 一 \\
\hline TUSC2 (FUS1) & $100 \%$ & $79 \%$ & $87 \%$ \\
\hline $\mathbf{R b}$ & $90 \%$ & $23-57 \%$ & $6-14 \%$ \\
\hline CDKN2A (P16) & $3-37 \%$ & $55 \%$ & $60-75 \%$ \\
\hline CDKN2A (P14ARF) & $65 \%$ & - & - \\
\hline \multicolumn{4}{|l|}{ DELETION / LOH } \\
\hline FHIT & $100 \%$ & 二 & 二 \\
\hline $\mathbf{R b}$ & $93 \%$ & - & 二 \\
\hline CDKN2A (P16) & $37 \%$ & - & - \\
\hline p53 & $86-93 \%$ & - & - \\
\hline \multicolumn{4}{|c|}{ TUMOR - ACQUIRED DNA METHYLATION } \\
\hline PTEN & & $24 \%$ & $30 \%$ \\
\hline APC & $15-26 \%$ & - & - \\
\hline FHIT & $64 \%$ & - & - \\
\hline RASSF1A & $72-85 \%$ & $31 \%$ & $43 \%$ \\
\hline CDH1 & $40-60 \%$ & - & - \\
\hline CDH13 & $15-20 \%$ & - & - \\
\hline CDKN2A (p16) & $0-5 \%$ & $21-36 \%$ & $24-33 \%$ \\
\hline CDKN2A (p14ARF) & NOT DETERMINED & - & - \\
\hline DAPK 1 & NOT DETERMINED & - & - \\
\hline CAV-1 & $9 \%$ & - & - \\
\hline SEMA3B & NOT DETERMINED & $46 \%$ & $47 \%$ \\
\hline MGMT & $10-30 \%$ & - & - \\
\hline GSTP1 & $7-15 \%$ & - & - \\
\hline RAR $\beta$ & $40-43 \%$ & - & - \\
\hline $\begin{array}{l}\text { TSGs : Tumor Suppre } \\
\text { LOH : Loss of Heteroz }\end{array}$ & $\begin{array}{l}\text { S SCLS : Small Cell Lu } \\
\text { SQCLC : Squamous }\end{array}$ & $\begin{array}{l}\text { ng Cancer LADC: } \\
\text { ell Lung Cancer }\end{array}$ & g Adenocarcinoma \\
\hline
\end{tabular}

Figure1:Tumor suppressor gene alterations in Lung Cancer

\section{REFERENCES}

[1] Siegel RL, Miller KD, Jemal A. Cancer statistics, 2018. CA Cancer J Clin 2018; 68:7-30.

[2] Surveillance, Epidemiology and End Results Program\&quot;. National Cancer Institute.

[3] Wistuba II, Gazdar AF. Lung cancer preneoplasia. Annu Rev Pathol 2006; 1:331-48.

[4] Sekido Y, Fong KM, Minna JD. Progress in understanding the molecular pathogenesis ofhuman lung cancer. BiochimBiophysActa 1998; 1378(1): F21-59.

[5] Nowell PC. The clonal evolution of tumor cell populations. Science 1976; 194(4260):23-8.

[6] Geutjes EJ, Bajpe PK, Bernards R. Targeting the epigenome for treatment of cancer. Oncogene 2012; 31(34):3827.

[7] Bjornsson HT, Sigurdsson MI, Fallin MD, Irizarry RA, Aspelund $\mathrm{T}$, Cui $\mathrm{H}$, et al.
Epigeneticalterations consist targets for cancer therapy intra-individual change over time in DNA methylation with familial clustering. JAMA 2008; 299(24):2877.

[8] Hanahan D, Weinberg RA. Hallmarks of cancer: the next generation. Cell 2011; 144(5):646-74.

[9] Larsen JE, Minna JD. Molecular biology of lung cancer: clinical implications. Clin ChestMed 2011; 32:703-40.

[10] Lynch TJ, Bell DW, Sordella R, Gurubhagavatula S, Okimoto RA, Brannigan $\mathrm{BW}$, et al.Activating mutations in the epidermal growth factor receptor underlying responsiveness ofnon-small-cell lung cancer to geftinib. N Engl J Med 2004; 350: 2129-39.

[11] Knudson AG. Antioncogenes and human cancer. Proc Natl AcadSci USA1993; 90:10914-21. 
[12] RasoMG,Wistuba II. Molecular pathogenesis of early-stage non-small cell lung cancer anda proposal for tissue banking to facilitate identification of new biomarkers. J ThoracOncol2007; 2:S128-35.

[13] Cully M, You H, Levine AJ, Mak TW. Beyond PTEN mutations: the PI3K pathway as anintegrator of multiple inputs during tumorigenesis. Nat Rev Cancer 2006; 6: 18492.

[14] Jin G, Kim MJ, Jeon HS, Choi JE, Kim DS, Lee EB, et al. PTEN mutations and relationshipto EGFR, ERBB2, KRS, and TP53 mutations in non-small cell lung cancers. Lung Cancer2010; 69: 279-83.

[15] Marsit CJ, Zheng S, Aldape K, Hinds PW, Nelson HH, WienckeJK, et al. PTEN expressionin non-small-cell lung cancer: evaluating its relation to tumor characteristics, allelic loss, andepigenetic alteration. Hum Pathol 2005; 36: 768-76.

[16] Escriva M, Peiro S, Herranz N, Villagrasa P, Dave N, Montserrat-Sentis B, et al. Repressionof PTEN phosphatase by Snail1 transcriptional factor during gamma radiationinduced apo-ptosis. Mol Cell Biol 2008; 28:1528-1540.

[17] Vasudevan KM, Gurumurthy S, Rangnekar VM. Suppression of pten expression by NFkappaB prevents apoptosis. Mol Cell Biol 2004;24: 1007-1021.

[18] Ohta M, Inoue H, Cotticelli MG, Kastury K, Baffa R, Palazzo J, et al. The FHIT gene, spanning the chromosome 3p14.2 fragile site and renal carcinoma-associated $\mathrm{t}(3 ; 8)$ breakpoint, isabnormal in digestive tract cancers. Cell 1996; 84: 587-597.

[19] Huang Q, Liu Z, Fang Xie, Liu C, Shao F, Zhu $\mathrm{C}$, et al. Fragile Histidine Triad (FHIT)Suppresses Proliferation and Promotes Apoptosis in Cholangiocarcinoma Cells by BlockingPI3K-Akt Pathway. Sci World J 2014; 179698.

[20] Rimessi A, Marchi S, Fotino C, Romagnoli A, Huebner K, Croce CM, et al. Intramitochondrial calcium regulation by the FHIT gene product sensitizes to apoptosis. Proc Natl AcadSci USA 2009; 106: 12753-8.

[21] Hassan MI, Naiyer A, Ahmad F. Fragile histidine triad protein: structure, function, and its association with tumorogenesis. J Cancer Res ClinOncol 2010;136: 333-50.

[22] Tan S, Sun C, Wei X, Li Y, Wu Y, Yan Z, et al. Quantitative assessment of lung cancerassociated with genes methylation in the peripheral blood. Exp Lung Res 2013; 39: 18290.

[23] Verri C, Roz L, Conte D, Liloglou T, Livio A, Vesin A, et al. Fragile histidine triad gene in-activation in lung cancer: the European Early
Lung Cancer project. Am J RespirCrit CareMed 2009; 179: 396-401.

[24] Cantor JP, Iliopoulos D, Rao AS, Druck T, Semba S, Han S-Y, et al. Epigenetic modulationof endogenous tumor suppressor expression in lung cancer xenografts suppresses tumorige-niccity. Int J Cancer 2007; 120: 2431 .

[25] Wistuba II, Gazdar AF, Minna JD. Molecular genetics of small cell lung carcinoma. SeminOncol 2001;28(2 Suppl 4): 3-13.

[26] Zöchbauer-Müller S, Wistuba II, Minna JD, Gazdar AF. Fragile histidine triad (FHIT) geneabnormalities in lung cancer. Clin Lung Cancer 2000; 2(2):141-5.

[27] Fong KM, Biesterveld EJ, Virmani A, Wistuba I, Sekido Y, Bader SA, et al. FHIT andFRA3B 3 p14.2 allele loss are common in lung cancer and preneoplastic bronchial lesionsand are associated with cancer-related FHIT cDNA splicing aberrations. Cancer Res 1997;57(11):2256-67.

[28] Fodde R, Kuipers J, Rosenberg C, Smits R, Kielman M, Gaspar C. Mutations in the APCtumour suppressor gene cause chromosomal instability. Nat Cell Biol 2001;3 : 433-8.

[29] Markowitz SD, Bertagnolli MM. Molecular origins of cancer: Molecular basis of colorectalcancer. New Engl J of Med 2009; 361(25): 2449-60

[30] Deng G, Song GA, Pong E, Sleisenger M, Kim YS. Promoter methylation inhibits APC ge-ne expression by causing changes in chromatin conformation and interfering with the bin-ding of transcription factor CCAAT-binding factor. Cancer Res 2004; 64: 2692-8.

[31] Usadel H, Brabender J, Danenberg KD, Jeronimo C, Harden S, Engles $\mathrm{J}$, et al. Quantitativeadenomatous polyposis coli promoter methylation analysis in tumor tissue, serum, and pla- sma DNA of patients with lung cancer. Cancer Res 2002; 62: 371-5.

[32] Tsou JA, Hagen JA, Carpenter CL, LairdOffringa IA. DNA methylation analysis: a power-ful new tool for lung cancer diagnosis. Oncogene 2002; 21 :5450-61.

[33] Chen Y, Li J, Yu X, Li S, Zhang X, Mo Z, et al. APC gene hypermethylation and prostate cancer: a systematic review and meta-analysis. Eur J Hum Genet 2013; 21: 929-35.

[34] Ohgaki H, Kros JM, Okamoto Y, Gaspert A, Huang H, Kurrer MO. APC mutations are infrequent but present in human lung cancer. Cancer Lett 2004; 207(2):197-203.

[35] Alessi DR, Sakamoto K, Bayascas JR. LKB1dependent signaling pathways. Annu Rev Biochem 2006; 75: 137-63. 
[36] Shaw RJ, Bardeesy N, Manning BD, Lopez L, Kosmatka M, DePinho RA, et al. The LKB1tumor suppressor negatively regulates mTOR signaling. Cancer Cell 2004; 6(1): 91-9.

[37] MarignaniPA.LKB1, the multitasking tumor suppressor kinase. J ClinPathol 2005; 58:15-9.

[38] Ding L, Getz G, Wheeler DA, Mardis ER, McLellan MD, Cibulskis K, et al. Somatic muta-tions affect key pathways in lung adenocarcinoma. Nature 2008; 455:1069-75.

[39] Hemminki A, Markie D, Tomlinson I, Avizienyte E, Roth S, Loukola A, et al. A serine/threo-nine kinase gene defective in Peutz-Jeghers syndrome. Nature 1998; 391(6663):184-7.

[40] Sanchez-Cespedes M, Parrella P, Esteller M, Nomoto S, Trink B, Engles JM, et al. Inactivation of LKB1/STK11 is a common event in adenocarcinomas of the lung. Cancer Res 2002;62(13): 3659-62.

[41] Koivunen JP, Kim J, Lee J, Rogers AM, Park $\mathrm{JO}$, Zhao X, et al. Mutations in the LKB1 tumour suppressor are frequently detected in tumours from Caucasion but not Asian lung cancer patients. Br J Cancer 2008; 99: 245-52.

[42] Matsumoto S, Iwakawa R, Takahashi K, Kohno T, Nakanishi Y, Y Matsuno Y, et al. Prevalence and specifcity of LKB1 genetic alterations in lung cancers. Oncogene 2007; 26:5911-8.

[43] Gill RK, Yang SH, Meerzaman D, Mechanic LE, Bowman ED, Jeon H-S, et al. Frequenthomozygous deletion of the LKB1/STK11 gene in non-small cell lung cancer. Oncogene2011; 30: 3784-91.

[44] Onozato R, Kosaka T, Achiwa H, Kuwano $\mathrm{H}$, Takahashi T, Yatabe $\mathrm{Y}$, et al. LKB1 genemutations in Japanese lung cancer patients. Cancer Sci 2007; 98: 1747-51.

[45] Ji L, Roth JA. Tumor suppressor FUS1 signaling pathway. J ThoracOncol. 2008; 3:327-30.

[46] Kondo M, Ji L, Kamibayashi C, Tomizawa Y, Randle D, Sekido Y, et al. Overexpression ofcandidate tumor suppressor gene FUS1 isolated from the $3 \mathrm{p} 21.3$ homozygous deletion regionleads to G1 arrest and growth inhibition of lung cancer cells.Oncogene 2001;20(43):6258-62.

[47] Uzhachenko R, Ivanov SV, Yarbrough WG, Shanker A, Medzhitov R, Ivanova AV. Fus1/Tusc2 is a novel regulator of mitochondrial calcium handling, Ca2+-coupled mitochondrialprocesses, and $\mathrm{Ca} 2+-$ dependent NFAT and NF-kappaB pathways in CD4+ T cells. AntioxidRedox Signal 2014; 20(10): 1533-47.

[48] Lin J, Sun T, Ji L,Deng W, Roth J, Minna J, Arlinghaus R. Oncogenic activation of c-Abl innon-small cell lung cancer cells lacking FUS1 expression: inhibition of $\mathrm{c}-\mathrm{Abl}$ by the tumorsuppressor gene product Fus1. Oncogene 2007; 26(49): 6989-96.

[49] Ivanova AV, Ivanov SV, Prudkin L, Nonaka D, Liu Z, Tsao A, et al. Mechanisms of FUS1/TUSC2 deficiency in mesothelioma and its tumorigenic transcriptional effects. Mol Cancer2009; 8:91.

[50] Lerman MI, Minna JD. The 630-kb lung cancer homozygous deletion region on humanChromosome 3p21.3: identification and evaluation of the resident candidate tumor suppres-sor genes. The International Lung Cancer Chromosome 3p21.3 Tumor Suppressor GeneCon-sortium. Cancer Res 2000; 60(21): 6116-33.

[51] Demokan S, Chuang AY, Chang X, Khan T, Smith IM, Pattani KM, et al. Identification ofguanine nucleotide-binding protein gamma-7 as an epigenetically silenced gene in head andneck cancer by gene expression profiling. Int J Oncol 2013; 42(4):1427-36.

[52] Bussemakers MJ, van Bokhoven A, Mees SG, Kemler R, Schalken JA. Molecular cloningand characterization of the human E-cadherin cDNA. MolBiol Rep 1993; 17:123-8.

[53] Karayiannakis AJ, Syrigos KN, Chatzigianni E, Papanikolaou S, Alexiou D, Kalahanis N, etal. Aberrant E-cadherin expression associated with loss of differentiation and advanced stagein human pancreatic cancer. Anticancer Res 1998; 18:4177-80.

[54] Zheng Z, Pan J, Chu B, Wong YC, Cheung AL, Tsao SW. Down-regulation and abnormalexpression of E-cadherin and betacatenin in nasopharyngeal carcinoma: close associationwith advanced disease stage and lymph node metastasis. Hum Pathol 1999; 30:458-66.

[55] Yasmeen A, Bismar TA, Al Moustafa AE. ErbB receptors and epithelial-cadherincatenincomplex in human carcinomas Future Oncol 2006; 2(6): 765-81.

[56] Gupta PB, Onder TT, Guozhi J. Identification of selective inhibitors of cancer stem cells byhigh-throughput screening Cell 2009; 138: 645-59.

[57] Myong NH. Reduced expression of CDH1 in human non-small cell lung carcinoma. CancerRes Treat 2004; 36(1): 56-61.

[58] Qiaowen Yu, QisenGuo, Liangan Chen, Shuwei Liu. Clinicopathological significance andpotential drug targeting of CDH1 in lung cancer: a meta-analysis and literature review. DrugDes DevelTher 2015; 9: 2171-8.

[59] Gessner C, Woischwill C, Schumacher A, Liebers U, Kuhn H, StiehlP, et al. Nuclear 
YBX1expression as a negative prognostic marker in non-small cell lung cancer EurRespir J 2004;23; 14-9.

[60] Stella GM, Luisetti M, Inghilleri S, Cemmi F, Scabini R, Zorzetto M, et al.Targeting EGFRin non-small-cell lung cancer: lessons, experiences, strategies Respir Med 2012;106 173-83.

[61] Xianfang Liu, Ling Su, Xiangguo Liu. Loss of CDH1 up-regulates epidermal growth factorreceptor via phosphorylation of YBX1 in non-small cell lung cancer cells. FEBS Letters2013; 587:3995-4000.

[62] Takeuchi T, Ohtsuki Y. Recent progress in Tcadherin(CDH13,H-cadherin) research. HistolHistopathol 2001; 16:1287-93.

[63] Stemmler MP. Cadherins in development and cancer. MolBiosyst 2008; 4:835-50.

[64] Drilon A, Sugita H, Sima CS, Zauderer M, Rudin CM, Kris MG, et al. A prospective studyof tumor suppressor gene methylation as a prognostic biomarker in surgically resected stageI to IIIA non-small-cell lung cancers. J ThoracOncol 2014; 9:1272-7.

[65] CelebilerCavusoglu A, Kilic Y, Saydam S, Canda T, Baskan Z, Sevinc AI, et al. Predictinginvasive phenotype with $\mathrm{CDH} 1$, CDH13, CD44, and TIMP3 gene expression in primarybreast cancer. Cancer Sci 2009; 100:2341-5.

[66] Toyooka KO, Toyooka S, Virmani AK, Sathyanarayana UG, Euhus DM, Gilcrease M, et al.Loss of expression and aberrant methylation of the CDH13 (H-cadherin) gene in breast andlung carcinomas. Cancer Res 2001; 61:4556-60.

[67] Putku M, Kals M, Inno R, Kasela S, Org E, Kozich V, et al. CDH13 promoter SNPs withpleiotropic effect on cardiometabolic parameters represent methylation QTLs. Hum Genet2015;134:291-303.

[68] Li Y, Li C, Yang Y, Shi L,Tao W, Liu S, et al. The association of six single nucleotide polymorphisms and their haplotypes in $\mathrm{CDH} 13$ with T2DM in a Han Chinese population. Medicine (Baltimore) 2017; 96: e7063.

[69] Park J, Kim I, Jung KJ, Kim S, Jee SH, Yoon SK. Gene-gene interaction analysis identifiesa new genetic risk factor for colorectal cancer. J Biomed Sci 2015; 11; 22:73.

[70] Yingfu Li, Chuanyin Li, Qianli Ma, Yu Zhang, Yueting Yao, Shuyuan Liu, et al.Genetic variation in $\mathrm{CDH} 13$ gene was associated with non-small cell lung cancer (NSCLC): A population-based case-control study. Oncotarget 2018; 9(1): 881-91.

[71] Shivakumar L, Minna J, Sakamaki T, Pestell R, White MA. The RASSF1A tumor suppressor blocks cell cycle progression and inhibits cyclin
D1 accumulation. Mol Cell Biol 2002; 22:30918.

[72] Ortiz-Vega S, Khokhatchev A, Nedwidek M, Zhang X, Dammann R, Pfeifer GP, et al. Theputative tumor suppressor RASSF1A homodimerizes and heterodimerizes with the Ras-GTPbinding protein Nore1. Oncogene 2002; 21, 1381-90.

[73] Dammann R, Li C, Yoon JH, Chin PL, Bates S, Pfeifer GP. Epigenetic inactivation of aRAS association domain family protein from the lung tumour suppressor locus $3 \mathrm{p} 21.3$. NatGenet 2000; 25:315-9.

[74] Zöchbauer-Müller S, Fong KM, Virmani AK, Geradts J, Gazdar AF, Minna JD. Aberrantpromoter methylation of multiple genes in non-small cell lung cancers. Cancer Res 2001; 6:249-55.

[75] Kumanogoh A, Kikutani H. The CD100-CD72 interaction: a novel mechanism of immuneregulation Trends Immunol 2001; 22: 670-6.

[76] Behar O, Golden JA, Mashimo H, Schoen FJ, Fishman MC. Semaphorin III is needed fornormal patterning and growth of nerves, bones and heart. Nature 1996; 383: 525-8.

[77] Gagliardini V, Fankhauser C. Semaphorin III can induce death in sensory neurons. Mol CellNeurosci 1999; 14: 301-6.

[78] Sekido Y, Bader S, Latif F, Chen JY, Duh FM, Wei MH, et al. Human semaphorins A(V)and IV reside in the 3 p21.3 small cell lung cancer deletion region and demonstrate distinctexpression patterns. Proc Natl AcadSci USA 1996; 93, 4120-5.

[79] Kuroki T, Trapasso F, Yendamuri S, Matsuyama A, Alder H, Williams NN, et al. Allelicloss on chromosome $3 \mathrm{p} 21.3$ and promoter hypermethylation of semaphorin 3B in non-smallcell lung cancer Cancer Res 2003; 63: 3352-5.

[80] Kolodkin AL, Matthes DJ, Goodman CS. The semaphorin genes encode a family of transmembrane and secreted growth cone guidance molecules. Cell 1993; 75: 1389-99.

[81] Tomizawa Y, Sekido Y, Kondo M, Gao B, Yokota J, Roche J,et al. Inhibition of lung cancer cell growth and induction of apoptosis after reexpression of $3 \mathrm{p} 21.3$ candidate tumor suppressor gene SEMA3B. Proc Natl AcadSci USA 98 2001; 13954-9.

[82] Ochi K, Mori T, Toyama Y, Nakamura Y, Arakawa H. Identification of Semaphorin3B as aDirect Target of p53. Neoplasia 2002; 4: 8287.

[83] Anderson RG, Jacobson K A role for lipid shells in targeting proteins to caveolae, rafts, andother lipid domains. Science (Wash DC) 2002; 296: 1821-5. 
[84] Nwosu ZC, Ebert MP, Dooley S, Meyer C. Caveolin-1 in the regulation of cell metabolism:a cancer perspective. Mol Cancer 2016' 15(1): 71 .

[85] Ketteler J, Klein D. Caveolin-1, cancer and therapy resistance. Int J Cancer 2018; 143(9):2092-2104

[86] Liu P, Rudick M, Anderson RG. Multiple functions of caveolin-1. J BiolChem 2002; 277:41295-8.

[87] Heighway J, Knapp T, Boyce L, Brennand S, Field JK, Betticher DC, et al. Expression profiling of primary non-small cell lung cancer for target identification. Oncogene 2002; 21:7749-63.

[88] Wikman H, Kettunen E, Seppanen JK, Karjalainen A, Hollmén J, Anttila S, et al. Identification of differentially expressed genes in pulmonary adenocarcinoma by using cDNA array.Oncogene 2002; 21: 5804-13.

[89] Kato K, Hida Y, Miyamoto M, Hashida $\mathrm{H}$, Shinohara T, Itoh T, et al. Overexpression of caveolin-1 in esophageal squamous cell carcinoma correlates with lymph node metastasis andpathologic stage. Cancer (Phila) 2002; 94: 929-33.

[90] Ho CC, Huang PH, Huang HY, Chen YH, Yang PC, Hsu SM. Up-regulated caveolin-1 accentuates the metastasis capability of lung adenocarcinoma by inducing filopodia formation. Am J Pathol 2002; 161: 1647-56.

[91] Wiechen K, Diatchenko L, Agoulnik A, ScharffKM, Schober H, ArltK, et al Caveolin1 isdown-regulated in human ovarian carcinoma and acts as a candidate tumor suppressor gene.Am J Pathol 2001; 159: 1635-43.

[92] Racine C, Belanger M, Hirabayashi H, Boucher M, Chakir J, Couet J. Reduction of caveolin1 gene expression in lung carcinoma cell lines. BiochemBiophys Res Commun 1999; 255:580-6.

[93] Srivenugopal KS, Ali-Osman F. The DNA repair protein, $\mathrm{O}(6)$-methylguanine-DNA methyltransferase is a proteolytic target for the E6 human papillomavirus oncoprotein. Oncogene 2002; 21: 5940-5.

[94] Kondo Y, Shen L, Issa JP. Critical role of histone methylation in tumor suppressor genesilencing in colorectal cancer. Mol Cell Biol 2003; 23(1):206-15.

[95] Guo M, House MC, Hooker C, Han Y, Heath E, Gabrielson E, et al. Promoter hypermethylation of resected bronchial margins: a field defect of changes. Clin Cancer Res 2004; 10, 5131-6.

[96] Zou XP, Zhang B, Zhang X-Q, Chen M, Cao J, Liu W-J, et al. Promoter hypermethylation of multiple genes in early gastric adenocarcinoma and precancerous lesions. HumPathol 2009; 40: 1534-42.
[97] Huang T, Chen X, Hong Q, Deng Z, Ma H, Xin $\mathrm{Y}$, et al. Meta-analyses of gene methylation and smoking behavior in non-small cell lung cancer patients. Sci Rep 2015; 5:8897.

[98] Etcheverry A, Aubry M, Idbaih A, Vauleon E, Marie Y, Menei $P$, et al. DGKI methylationstatus modulates the prognostic value of MGMT in glioblastoma patients treated with combined radio-chemotherapy with temozolomide. PLoS One 2014; 9(9):e104455.

[99] Asiaf A, Ahmad ST, Malik AA, Aziz SA, Rasool Z, Masood A, et al. Protein expressionand methylation of MGMT, a DNA repair gene and their correlation with clinicopathological parameters in invasive ductal carcinoma of the breast. TumourBiol 2015; 36(8):6485-96.

[100] Guo M, Alumkal J, Drachova T, Marina SS, Jen $J$, et al. CHFR methylation strongly correlates with methylation of DNA damage repair and apoptotic pathway genes in nonsmallcell lung cancer. Discov Med 2015; 19: 151-8.

[101] Yang Z, Li F. O-6-methylguanine-DNA methyltransferase gene promoter methylation andlung cancer risk: A meta-analysis. J Cancer Res Ther 2016; 12: C233-6.Fang N, Gu J, Wei H, You J, Zhou Q. A meta-analysis of association between MGMT

[102] gene promoter methylation and non-small cell lung cancer. ZhongguoFei Ai ZaZhi 2014;17: 601-5.

[103] Gu C, Lu J, Cui T, Lu C, Shi H, Xu W, et al. Association between MGMT promoter methylation and non-small cell lung cancer: a meta-analysis. PLoS One 2013; 8: e72633.

[104] Mogi A, Kuwano H. TP53 mutations in nonsmall cell lung cancer. J Biomed Biotech 2011; 2011:583929.

[105] Eymin B, Gazzeri S, Brambilla C, et al.Mdm2 over- '...' pathway in response to genotoxicstress. Mol Cell Biol 2006; 26:4339-50.

[106] Olivier M, Petitjean A, Marcel V, PétréA, Mounawar M, Plymoth A, et al. Recent advances in p53 research: an interdisciplinary perspective. Cancer Gene Ther 2009; 16:1-12.

[107] Gazzeri S, Della Valle V, Chaussade L, Brambilla C, Larsen CJ, Brambilla E. The humanp19ARF protein encoded by the beta transcript of the p16INK4a gene is frequently lost insmall cell lung cancer. Cancer Res 1998; 58:3926-31.

[108] Wistuba II, Berry J, Behrens C, Maitra A, Shivapurkar N, Milchgrub S, et al. Molecularchanges in the bronchial epithelium of patients with small cell lung cancer. Clin CancerRes 2000; 6: 2604-10. 
[109] D’Amico D, Carbone D, Mitsudomi T, Nau M, Fedorko J, Russell E, et al. High frequencyof somatically aquired p53 mutations in small-cell lung cancer cell lines and tumors. Oncogene 1992; 7:339-46.

[110] Brambilla E, Gazzeri S, Lantuejoul S, Coll JL. p53 mutant immunophenotype and deregulation of p53 transcription pathway (Bcl2, Bax, and Waf1) in precursor bronchial lesions oflung cancer. Clin Cancer Res 1998; 4: 1609-18.

[111] Jeanmart M, Lantuejoul S, Fievet F, Moro D, Sturm N, BrambillaC,et al. Value of immunohistochemical markers in preinvasive bronchial lesions in risk assessment of lung cancer.Clin Cancer Res 2003; 9: 2195-2203.

[112] Tammemagi MC, McLaughlin JR, Bull SB. Meta-analyses of p53 tumor suppressor genealterations and clinicopathological features in resected lung cancers. Cancer EpidemiolBiomarkers Prev 1999; 8: 625-34.

[113] Cancer Genome Atlas Research Network. Comprehensive genomic characterization ofsquamous cell lung cancers. Nature 2012; 489: 519-25.

[114] Kosaka T, Yatabe Y, Endoh H, Kuwano H, Takahashi T, Mitsudomi T. Mutations of theepidermal growth factor receptor gene in lung cancer: biological and clinical implications.Cancer Res 2004; 64: 8919-23.

[115] Husgafvel-Pursiainen K, Boffetta P, Kannio A, Nyberg F, Pershagen G, Mukeria A, et al.p53 mutations and exposure to environmental tobacco smoke in a multicenter study on lungCancer. Cancer Res 2000; 60: 2906-11.

[116] Takagi Y, Osada H, Kuroishi T, Mitsudomi T, Kondo M, Niimi T, et al. p53 mutations innonsmall-cell lung cancers occurring in individuals without a past history of active smoking. Br J Cancer 1998; 77: 1568-72.

[117] Steels E, Paesmans M, Berghmans T, Branle F, Lemaitre F, Mascaux C, et al. Role of p53as a prognostic factor for survival in lung cancer: a systematic review of the literature witha meta-analysis. EurRespir J 2001; 18: 705-19.

[118] van Oijen MG, Slootweg PJ. Gain-of-function mutations in the tumor suppressor gene p53.Clin Cancer Res 2000; 6(6): 2138-45.

[119] Brambilla E, Gazdar A. Pathogenesis of lung cancer signaling pathways: roadmap fortherapies. EurRespir J 2009 J; 33(6): 1485-97.

[120] Germain P, Chambon P, Eichele G, Evans RM, Lazar MA, Leid $M$, et al. InternationalUnion of Pharmacology. LX. Retinoic acid receptors. Pharmacol Rev 2006; 58 (4):712-25.

[121] Allenby G, Bocquel MT, Saunders M, Kazmer $\mathrm{S}$, Speck J, Rosenberger M, et al. Retinoicacid receptors and retinoid $\mathrm{X}$ receptors: interactions with endogenous retinoic acids. ProcNatl AcadSci USA 1993; 90 (1): 30-4.

[122] Sun SY, Lotan R. Retinoids and their receptors in cancer development and chemoprevention. Crit Rev OncolHematol2002; 41(1):41-55.

[123] Evans RM. The steroid and thyroid hormone receptor superfamily. Science 1988; 240:88995.

[124] Petty WJ, Li N, Biddle A. A novel retinoic acid receptor beta isoform and retinoid resistance in lung carcinogenesis. J Natl Cancer Inst 2005; 97(22):1645-51.

[125] Evans TR, Kaye SB. Retinoids: present role and future potential. Br J Cancer 1999; 80:1-8.

[126] Houle B, Leduc F, Bradley WE. Implication of RARB in epidermoid (Squamous) lungcancer. Genes Chromosomes Cancer 1991; 5:358-66.

[127] Xu XC, Sozzi G, Lee JS, Lee JJ, Pastorino U, Pilotti $S$, et al. Suppression of retinoic acidreceptor beta in non-small-cell lung cancer in vivo: implications for lung cancer development. J Natl Cancer Inst 1997; 89:624-9.

[128] Gebert JF, Moghal N, Frangioni JV, Sugarbaker DJ, Neel BG. High frequency of retinoicacid receptor beta abnormalities in human lung cancer. Oncogene 1991; 6:1859-6.

[129] Xu XC, Ro JY, Lee JS, Shin DM, Hong WK, Lotan R. Differential expression of nuclearretinoid receptors in normal, premalignant, and malignant head and neck tissues. CancerRes 1994; 54: 3580-7.

[130] Widschwendter M, Berger J, Daxenbichler G, Müller-Holzner E, Widschwendter A, MayrA, et al. Loss of retinoic acid receptor beta expression in breast cancer and morphologically normal adjacent tissue but not in the normal breast tissue distant from the cancer. CancerRes 1997; 57:4158-61.

[131] Picard E, Seguin C, Monhoven N, RochetteEgly C, Siat J, Borrelly J, et al. Expression ofretinoid receptor genes and proteins in nonsmall-cell lung cancer. J Natl Cancer Inst 1999;91:1059-66.

[132] Baylin SB, Esteller M, Rountree MR, Bachman KE, Schuebel K, Herman JG. Aberrantpatterns of DNA methylation, chromatin formation and gene expression in cancer. HumMol Genet 2001; 10:687-92.

[133] Virmani AK, Rathi A, Zöchbauer-Müller S, Sacchi N, Fukuyama Y, Bryant D, et al. Promoter methylation and silencing of the retinoic acid receptor-beta gene in lung carcinomas. J Natl Cancer Inst 2000; 92: 1303-7.

[134] Toma S, Emionite L, Fabia G, Spadini N, Vergani L. Chemoprevention of tumors: the roleof RAR-beta. Int J Biol Markers 2003; 18:78-81. 
[135] Ohtani N, Yamakoshi K, Takahashi A, Takahashi A, Hara E. The p16INK4a-RB pathway:molecular link between cellular senescence and tumor suppression. J Med Invest 2004; 51:146-53.

[136] Iwakawa R, Kohno T, Anami Y, Noguchi M, Suzuki K, Matsuno Y, et al. Association ofp16 homozygous deletions with clinicopathologic characteristics and EGFR/KRAS/p53mutations in lung adenocarcinoma. Clin Cancer Res 2008; 14(12): 374-53.

[137] Sanchez-Cespedes M, Reed A, Buta M, Wu L, Westra WH, Herman JG, et al. Inactivationof the INK4A/ARF locus frequently coexists with TP53 mutations in non-small cell lungcancer. Oncogene 1999; 18: 5843-9.

[138] Seike M, Gemma A, Hosoya Y, Hemmi S, Taniguchi Y, Fukuda Y,et al. Increase in frequency of p16INK4A gene inactivation by hypermethylation in lung cancer during the process of metastasis and its relation to the status of p53. Clin Cancer Res 2000; 6:4307-13.

[139] Kraunz K, Nelson H, Lemos M, Godleski JJ, Wiencke JK, Kelsey KT. Homozygous deletion of p16INK4a and tobacco carcinogen exposure in nonsmall cell lung cancer. Int $\mathbf{J}$ Cancer 2006; 118:1364-9.

[140] Toyooka S, Suzuki M, Tsuda T, Toyooka KO, Maruyama R, Tsukuda K, et al. Dose effectof smoking on aberrant methylation in non-small cell lung cancers. Int J Cancer 2004; 110:462-4.

[141] Kim D, Nelson H, Wiencke J, Zheng S, Christiani DC, Wain JC, et al. p16INK4a and Histology-specific Methylation of CpG Islands by Exposure to Tobacco Smoke in NonSmallCell Lung Cancer. Cancer Res 2001; 61:3419-24.

[142] Knudson AG, Meadows AT, Nichols WW, Hill R. Chromosomal deletion and retinoblastoma. N Engl J Med 1976; 295(20): 1120-3.

[143] Kleinerman RA, Tarone RE, Abramson DH, Seddon JM, Li FP, Tucker MA. Hereditaryretinoblastoma and risk of lung cancer. J Natl Cancer Inst 2000; 92(24):2037-9.

[144] Marees T, Moll AC, Imhof SM, de Boer MR, RingensPJ,vanLeeuwen FE. Risk of secondmalignancies in survivors of retinoblastoma: more than 40 years of follow-up. J Natl CancerInst 2008;100 (24):1771-9.

[145] Trimarchi JM, Lees JA. Sibling rivalry in the E2F family. Nat Rev Mol Cell Biol 2002; 3:11-20.

[146] Egger JV, Lane MV, Antonucci LA, Dedi B, Krucher NA. Dephosphorylation of the retinoblastoma protein $(\mathrm{Rb})$ inhibits cancer cell EMT via Zeb. Cancer BiolTher 2016; 7(11):1197-1205.

[147] Schaal C, Pillai S, Chellappan SP. The Rb-E2F transcriptional regulatory pathway in tumorangiogenesis and metastasis. Adv Cancer Res 2014; 121:147-82.

[148] Hutcheson J, Witkiewicz AK, Knudsen ES. The RB tumor suppressor at the intersection ofproliferation and immunity: relevance to disease immune evasion and immunotherapy. CellCycle 2015; 14(24):3812-9.

[149] Otterson GA, Kratzke RA, Coxon A, Kim YW, Kaye FJ. Absence of p16INK4 protein isrestricted to the subset of lung cancer lines that retains wildtype RB. Oncogene 1994;9(11):3375-8.

[150] Weir BA, Woo MS, Get z G, Perner S, Ding L, Beroukhim R, et al. Characterizing thecancer genome in lung adenocarcinoma. Nature 2007;450:893-8.

[151] Gouyer V, Gazzeri S, Bolon I, Drevet C. Mechanism of retinoblastoma gene inactivationin the spectrum of neuroendocrine lung tumors. Am J Respir Cell MolBiol 1998; 18:188-96.

[152] Brambilla E, Moro D, Gazzeri S, Brambilla C. Alterations of expression of Rb, p16(INK4A) and cyclin D1 in non-small cell lung carcinoma and their clinical significance. J Pathol1999; 188:351-60.

[153] Brambilla E, Gazzeri S, Moro D, Lantuejoul S, Veyrenc S, Brambilla C. Alterations of Rbpathway (Rb-p16INK4-cyclin D1) in preinvasive bronchial lesions. Clin Cancer Res 1999; 5:243-50.

[154] Cohen O, Kimchi A. DAP-kinase: from functional gene cloning to establishment of its rolein apoptosis and cancer. Cell Death Differ 2001; 8:6-15.

[155] Tang X, Wu W, Sun SY, Wistuba II, Hong WK, et al. Hypermethylation of the deathassociated protein kinase promoter attenuates the sensitivity to TRAIL-induced apoptosis in

[156] human non-small cell lung cancer cells. Mol Cancer Res 2004; 2: 685-91.Michie AM, McCaig AM, Nakagawa R, Vukovic $M$. Death-associated protein kinase(DAPK) and signal transduction: regulation in cancer. FEBS J 2010; 277: 74-80.

[157] Katzenellenbogen RA, Baylin SB, Herman JG. Hypermethylation of the DAP-kinase CpGisland is a common alteration in B-cell malignancies. Blood 1999; 93:4347-53.

[158] Kim DH, Nelson HH, Wiencke JK, Christiani DC, Wain JC, Mark EJ. Promoter methylation of DAP-kinase: association with advanced stage in non-small cell lung cancer. Oncogene 2001; 20: 1765-70. 
[159] Niklinska W, Naumnik W, Sulewska A, Kozlowski M, Pankiewicz W, Milewski R. Prognostic significance of DAPK and RASSF1A promoter hypermethylation in nonsmallcell lung cancer (NSCLC) Folia HistochemCytobiol 2009;47:275-80.

[160] Vallbohmer D, Brabender J, Yang D, Schneider PM, Metzger R, Danenberget KD, et al.DNA methyltransferases messenger RNA expression and aberrant methylation of CpGislands in non-small-cell lung cancer: association and prognostic value. Clin Lung Cancer2006; 8:39-44.

[161] Wang Y, Zhang D, Zheng W, Luo J, Bai Y, Lu Z. Multiple gene methylation of nonsmallcell lung cancers evaluated with 3-dimensional microarray. Cancer 2008; 112:1325-36.

[162] Yanagawa N, Tamura G, Oizumi H, Takahashi N, Shimazaki Y, Motoyama T. Promoterhypermethylation of tumor suppressor and tumor-related genes in nonsmall cell lung cancers. Cancer Sci 2003; 94:589-92.

[163] Simpson DJ, Clayton RN, Farrell WE. Preferential loss of death associated protein kinaseexpression in invasive pituitary tumours is associated with either $\mathrm{CpG}$ island methylation orhomozygous deletion. Oncogene 2002; 21:1217-24.

[164] López-Cima MF, Alvarez-Avellón SM, Pascual T, Fernandez-Somoano A, Tardón A. Genetic polymorphisms in CYP1A1, GSTM1, GSTP1 and GSTT1 metabolic genes and risk ofof lung cancer in Asturias. BMC Cancer 2012; 12: 433.

[165] Shukla RK, Kant S, Mittal B, Bhattacharya S. Polymorphism of cytochrome p450, glutathione-s-transferase and Nacetyltransferases: influence on lung cancer susceptibility.NigerJ Med 2010; 19(3):257-63.

[166] Josephy PD. Genetic variations in human glutathione transferase enzymes: significance forpharmacology and toxicology. Hum Genomics Proteomics 2010; 2010; 2010: 87 6940.

[167] Altinisik J, Balta ZB, Aydin G, Ulutin T, Buyru N. Investigation of glutathione S-transferase M1 and T1 deletions in lung cancer. MolBiol Rep 2010; 37(1): 263-7.

[168] Hayes JD, Flanagan JU, Jowsey IR. Glutathione transferases. Annu Rev Pharmacol Toxicol 2005; 45: 51-88.

[169] [Meiers I. Glutathione S-Transferase pi (GSTP1) Atlas Genet Cytogenet Oncol Haematol 2010; 14(12):1181-5.

[170] Ada AO, Kunak SC, Hancer F, Soydas E, Alpar S, Gulhan M, et al. Association betweenGSTM1, GSTT1, and GSTP1 polymorphisms and lung cancer risk in a Turkish population.MolBiol Rep 2012;39(5): 5985-93.

[171] Ramzy MM, Solliman MEDM, Abdel-Hafiz HA, Salah R. Genetic polymorphism of GSTM1 and GSTP1 in lung cancer in Egypt. Int J Collab Res Intern Med Public Health 2011; 3:41-51.

[172] Robertson IG, Guthenberg C, Mannervik B, Jernström B. Differences in stereoselectivityand catalytic efficiency of three human glutathione transferases in the conjugation of glutathione with 7 beta, 8 alphadihydroxy-9 alpha, 10 alpha-oxy7,8,9,10-tetrahydro-benzo(a) pyrene. Cancer Res 1986; 46(5): 2220-4.

[173] Denissenko MF, Pao A, Tang M, Pfeifer GP. Preferential formation of benzo [a]pyreneadducts at lung cancer mutational hotspots in P53. Science 1996; 274(5286): 430-2.

[174] Kinzler KW, Vogelstein B. Cancersusceptibility genes. Gatekeepers and caretakers. Nature 1997; 386(6627):761,763.

Citation: Nikolaos Andreas Chrysanthakopoulos, The Role of Tumor Suppressor Genes in Molecular and Biological Basis of Lung Cancer. ARC Journal of Cancer Science. 2020; 6(1):29-45. DOI:doi.org/10. 20431/2455-6009.0601005.

Copyright: (C) 2020 Authors. This is an open-access article distributed under the terms of the Creative Commons Attribution License, which permits unrestricted use, distribution, and reproduction in any medium, provided the original author and source are credited. 